\title{
Quality of bananas harvested at different development stages and subjected to cold storage ${ }^{1}$
}

\author{
Thais Cristina Santos², Flávia Soares Aguiar², \\ Maria Luisa Mendes Rodrigues ${ }^{2}$, Gisele Polete Mizobutsi² ${ }^{2}$ Juceliandy Mendes da Silva Pinheiro ${ }^{2}$
}

\begin{abstract}
One of the biggest problems faced by banana growers is to determine the most appropriate harvest time. This study aimed to evaluate the post-harvest conservation of 'PrataAnã' bananas harvested at 16, 17, 18, 19 and 20 weeks after the inflorescence emergence and subjected to 25 days of cold storage at the temperature of $13.5^{\circ} \mathrm{C}\left( \pm 1^{\circ} \mathrm{C}\right)$ and $90 \%( \pm 5 \%)$ of relative humidity. The bananas harvested at 19 and 20 weeks after the inflorescence emergence showed a more advanced maturity stage after 25 days of cold storage at $13.5{ }^{\circ} \mathrm{C}$. The bananas showed an increase in the content of soluble solids, as well as sugars, during the evaluations, after withdrawal from the cold room. Regardless of the fruit age, there was a decrease in the $\mathrm{pH}$ values over the 9 days of evaluation, after the 25-day storage period. The fruits at the ages of 19 and 20 weeks presented, on average, starch contents lower than those of the fruits with 16,17 and 18 weeks. Fruits at the ages of 19 and 20 weeks showed higher extravasation levels on the second day of evaluation. Both the fruit harvest time and storage temperature directly influenced the post-harvest conservation and the physical and chemical characteristics of the 'Prata-Anã' bananas.
\end{abstract}

KEYWORDS: Musa sp;; post-harvest conservation; harvest time.

\section{INTRODUCTION}

Bananas are among the world's most important fruits, both in terms of production and marketing. Brazil ranks fourth in banana production, behind India, China and the Philippines (FAO 2016). In the 2016 harvest, in Brazil, the production reached 6.8 million tons and yield was $14,401 \mathrm{~kg} \mathrm{ha}^{-1}$.

In Brazil, one of the biggest problems faced by banana growers is to determine the best time to harvest the fruits, since harvesting at an inadequate

\section{RESUMO}

Qualidade de bananas submetidas a colheitas em diferentes períodos de desenvolvimento e armazenamento refrigerado

Um dos maiores problemas enfrentados pelos produtores de banana é a determinação do momento oportuno da colheita. Objetivou-se avaliar a conservação pós-colheita de bananas 'PrataAnã' colhidas com 16, 17, 18, 19 e 20 semanas após a emissão da inflorescência e submetidas a 25 dias de armazenamento refrigerado à temperatura de $13,5^{\circ} \mathrm{C}\left( \pm 1{ }^{\circ} \mathrm{C}\right)$ e $90 \%( \pm 5 \%)$ de umidade relativa. As bananas colhidas com 19 e 20 semanas após a emissão da inflorescência apresentaram estádio mais avançado de maturação após 25 dias de armazenamento refrigerado a $13,5^{\circ} \mathrm{C}$. As bananas apresentaram aumento no teor de sólidos solúveis, bem como de açúcares, no decorrer das avaliações, após retiradas da câmara frigorífica. Independentemente da idade dos frutos, houve redução nos valores de $\mathrm{pH}$ durante os 9 dias de avaliação, após os 25 dias de armazenamento. Os frutos com 19 e 20 semanas apresentaram, em média, teores de amido inferiores aos frutos com 16,17 e 18 semanas. Frutos com idades de 19 e 20 semanas apresentaram maiores teores de extravasamento no segundo dia de avaliação. A idade de colheita do fruto e a temperatura de armazenamento influenciaram diretamente na conservação pós-colheita e nas características físicas e químicas das bananas 'Prata Anã'.

PALAVRAS-CHAVE: Musa sp.; conservação pós-colheita; época de colheita.

time may cause the fruit to become unsuitable for marketing (Lichtemberg et al. 2016). Banana fruits are harvested at a green, but physiologically developed stage [maturity stage 1, as per Von Loesecke's classification standards (PBMH \& PIF 2006)], and, for being climacteric, they complete their ripening after harvesting (Castricini et al. 2015).

According to Borges \& Souza (2004), guiding methods for determining the best harvest time include: physiological stage, fruit diameter and fruit diameter by age. Chitarra \& Chitarra (2005) suggest

1. Manuscript received in Jan./2018 and accepted for publication in May/2018 (http://dx.doi.org/10.1590/1983-40632018v4851297).

2. Universidade Estadual de Montes Claros, Departamento de Ciências Agrárias, Janaúba, MG, Brasil.

E-mails: thaiscristinasantos97@gmail.com, fsa.agronomia@gmail.com, marialuisamendes@yahoo.com.br, gisele.mizobutsi@unimontes.br, juceliandy@yahoo.com.br. 
taking into account the days from the inflorescence emergence, desiccation of leaves, fragility of floral extremities, pulp consistency and changes or disappearance of fruit angularity. Some growers have individually adopted one of these methods, and they have not yet decided on a definite and safe protocol for harvesting 'Prata-Anã' bananas, since the fruits keep having square edges even when ripe.

The use of conservation techniques, such as cold storage and modified atmosphere, contributes to increasing the marketing period and reducing losses caused by the deterioration of the fruits, hence reducing post-harvest losses (Serpa et al. 2014).

The use of cold storage alone or combined with fruit age may enhance the post-harvest conservation of 'Prata-Anã' bananas for the necessary amount of time to guarantee that the product will have the quality and the characteristics desired by the consumer market. In view of the above, this study aimed to evaluate the post-harvest conservation of 'Prata-Anã' bananas harvested, separated from bunches, at different ages and subjected to a 25-day storage period at $13.5^{\circ} \mathrm{C}$.

\section{MATERIAL AND METHODS}

The fruits were grown at the experimental farm of the Universidade Estadual de Montes Claros, in Janaúba, Minas Gerais state, Brazil. The plants were weekly marked after the inflorescence emergence, from 14 April to 12 May (2016). A specific day of the week was defined for the markings, and the fruits were harvested on 1 September (when the bunches marked at the first week completed 20 weeks), thus resulting in bunches at the ages of 16, 17, 18, 19 and 20 weeks after the inflorescence emergence.

After the harvest, the bunches were sent to the laboratory, where the second, third and fourth tiers on the stalk were plucked and selected, being separated into bouquets of four fruits each, and each bouquet considered a repetition. To avoid diseases, the fruits were immersed in a Magnate ${ }^{\circledR}$ fungicide solution, at a dose of $2 \mathrm{~mL} 1,000 \mathrm{~mL}^{-1}$ of water, and dried in ambient air.

Each bouquet was packed in $25-\mu$ m-thick low-density polyethylene packaging, placed in standard boxes for export and stored in a cold room at $13.5^{\circ} \mathrm{C} \pm 1{ }^{\circ} \mathrm{C}$ and $90 \%$ ( $\pm 5 \%$ ) of relative humidity, for 25 days. After this storage period, the fruits were withdrawn from cold room and packaging and kept at $25^{\circ} \mathrm{C}$, for physical and chemical analyses, at twoday intervals (1, 3, 5, 7 and 9 days after cold storage), simulating the marketing period.

The peel and pulp firmness analysis was based on the maximum penetration force of a 6-mm diameter flat tip, from a distance of $10 \mathrm{~mm}$, using a digital penetrometer, with results expressed in Newton (N). The fruit peel was stained by a Color Flex 45/0 (2200) colorimeter, stdzMode: 45/0 with direct reflectance reading of coordinates $\mathrm{L}^{*}$ (lightness), a* (red/green hue) and b* (yellow/blue hue) of the Hunterlab Universal Software system. Based on the values of $a^{*}$ and $b^{*}$, the hue angle $\left({ }^{\circ} \mathrm{h}^{*}\right)$ and the chromaticity saturation index $\left(\mathrm{C}^{*}\right)$ were calculated.

To determine the $\mathrm{pH}$ and titratable acidity, $10 \mathrm{~g}$ of crushed pulp were used in $90 \mathrm{~mL}$ of distilled water. The $\mathrm{pH}$ was determined by direct measurement with a bench potentiometer, and titratable acidity was determined by titration with $0.1 \mathrm{~N}$ sodium hydroxide, using $1 \%$ phenolphthalein as indicator, with results expressed as $\mathrm{g}$ of malic acid $* 100 \mathrm{~g}^{-1}$ of pulp. Soluble solids were determined by refractometry, using a bench refractometer (ATAGO, model N1) with a wide measurement range (Brix: 0-95\%).

Starch was extracted and dosed by the Somoghy method, as adapted by Nelson (1944), and expressed in percentage of fresh pulp. Total and reducing sugars were determined according to the Nelson's (1944) and Dische's (1962) methods. Nonreducing sugars were quantified by calculating the difference between total sugar and reducing sugar $\mathrm{x}$ 0.95 , with results expressed in percentage.

Electrolyte extravasation was determined according to the method described by Whilton et al. (1992). The results were expressed as the ratio between the values obtained in the first and second measurements, multiplied by 100 .

The experimental design was completely randomized, in a 5 x 5 factorial arrangement (bunch ages $\mathrm{x}$ five evaluation periods after cold storage). Four replicates and four fruits per replicate were used. The evaluated data were submitted to variance analysis by the $\mathrm{F}$ test, verifying the significance of the factors tested. Regression models were adjusted, selecting the model with the highest coefficient of determination and that one that could better explain the biological phenomenon. The Sisvar statistical analysis software (Ferreira 2011) was used for the data analysis processing. 


\section{RESULTS AND DISCUSSION}

The results of the fruit physical analyses showed that there were significant differences in relation to the evaluated variables, except for lightness. The data displayed in Figure 1 show that, for chromaticity, regardless of the age of the bunch, there was an increase in the values from 43.02 to 47.6, during the 9 days of evaluation after the fruits were withdrawn from the cold room. An increase in color intensity was observed as a result of the appearance of other pigments, other than the chlorophyll present in the fruits. According to Mendonça et al. (2003), chromaticity expresses the color intensity, i.e., saturation, in terms of pigments of that color.

There was a significant interaction between bunch age and evaluation time, regarding the values found for hue angle of the fruit peel. Higher values were found for fruits that were 16,17 and 18 weeks old, after 25 days of cold storage, with a mean decrease from $105.45^{\circ}$ to $83.46^{\circ}$ over the 9 days of evaluations (Figure 2). This result evinces the initial evolution of the color hue of the banana peel from green to yellow, observed more intensely in fruits coming from 20 -week-old bunches, which probably had already entered the process of senescence, when the values ranged from $94.60^{\circ}$ to $75.39^{\circ}$. Castricini et al. (2015) found hue angle values of $115.99^{\circ}$ and $92.71^{\circ}$, respectively at the commercial harvest time and at the maturity stage 6 . According to Prill et al. (2012), a peel color variation during ripening possibly occurs due to the process of chlorophyll degradation, in relation to the respiratory metabolism of the fruit.

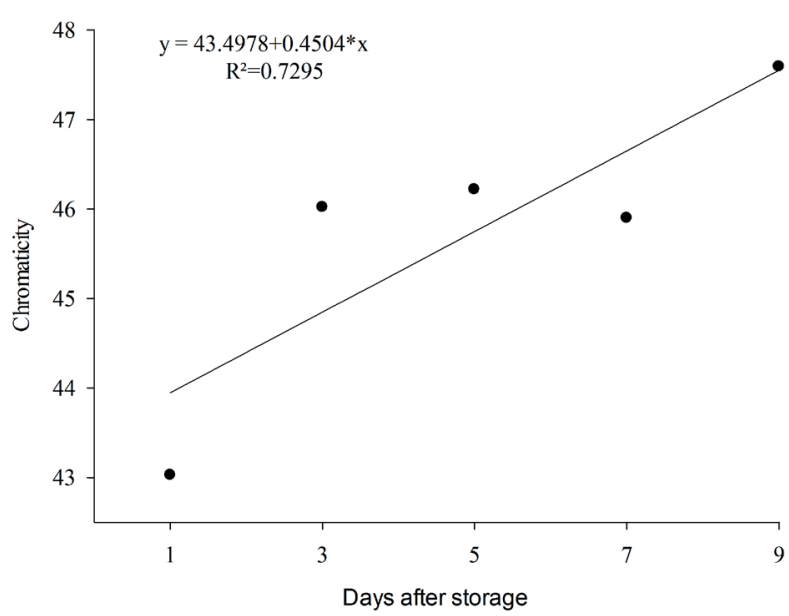

Figure 1. Chromaticity variation of 'Prata-Anã' bananas peel, in ambient conditions, after cold storage.
Peel and pulp firmness decreased with each day of evaluation as the fruits ripened (Figures 3 and 4). According to Chitarra \& Chitarra (2005), the decrease in firmness may be related to the loss of cell wall integrity, due to enzymatic hydrolysis by the action of pectinolytic enzymes: poligaracturonase and pectinamethylesterase, as well as cellulases and $\beta$-galactosides. According to Mohapatra et al. (2011), besides the hydrolysis of starch and solubilization of pectic substances in the cell wall, fruit softening may also be associated with the increase in the pulp moisture, due to osmotic exchanges with the peel, resulting in loss of turgescence.

The results of the study were similar to those reported by Sarmento et al. (2012), who studied 'Valery' cultivars stored at $14{ }^{\circ} \mathrm{C}$ and observed a marked reduction in fruit firmness after transfering to ambient temperature conditions $\left(27^{\circ} \mathrm{C} \pm 2{ }^{\circ} \mathrm{C}\right.$ and relative humidity of $55 \% \pm 5 \%$ ). The same can be observed in other varieties, as reported by Sarmento et al. (2015) for 'Catarina' banana, who observed that, during the storage period, the firmness values of fruit pulp reduced significantly from $46.45 \mathrm{~N}$ to $5.69 \mathrm{~N}$, as maturation progressed.

There was no significant effect between bunch age and days after cold storage for soluble solids contents. A significant effect was observed only with regard to the evaluation days (Figure 5). The values

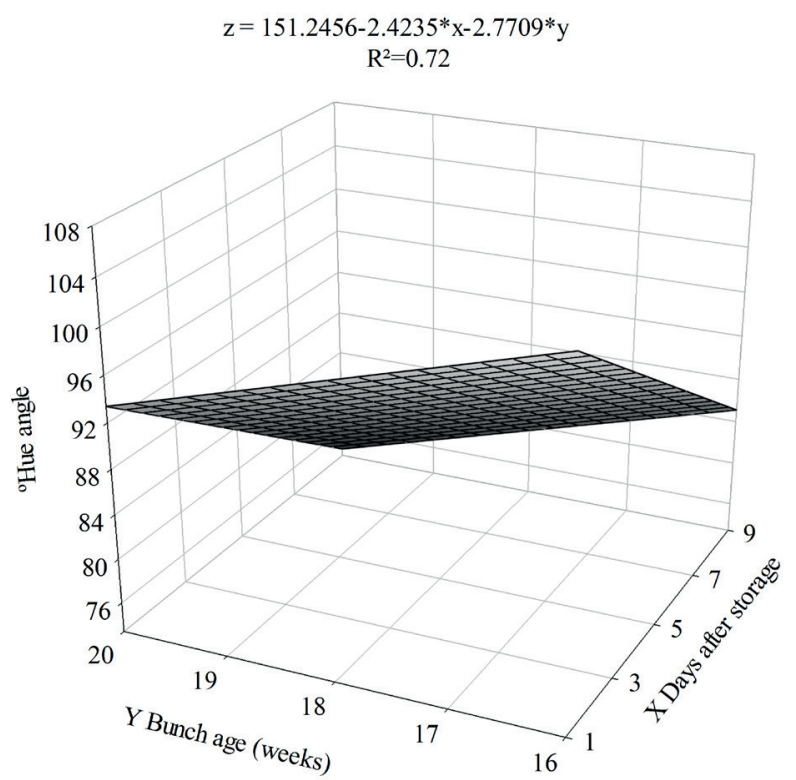

Figure 2. ${ }^{\circ}$ Hue angle variation on the peel of 'Prata-Anã' bananas separated from bunches at different ages, in ambient conditions, after 25 days of cold storage. 
found for soluble solids ranged from $6.13^{\circ}$ Brix to $24.45^{\circ}$ Brix, during the 9 days of evaluation after the fruits were taken from the cold room. Soluble solids indicate the amount, in grams, of the solids that are dissolved in the juice or pulp. They are measured in ${ }^{\circ}$ Brix, are used as an indirect measure of sugar content and increase with maturation by means of synthetic processes or by polysaccharide degradation (Chitarra \& Chitarra 2005). Sarmento et al. (2015) also observed an increase in the soluble solids contents, when studying the post-harvest conservation of 'Catarina' banana, with a maximum value of $24.1^{\circ} \mathrm{Brix}$ on the eighth day of storage at room temperature $\left(27.5^{\circ} \mathrm{C}\right.$ and relative humidity of $62.5 \%)$

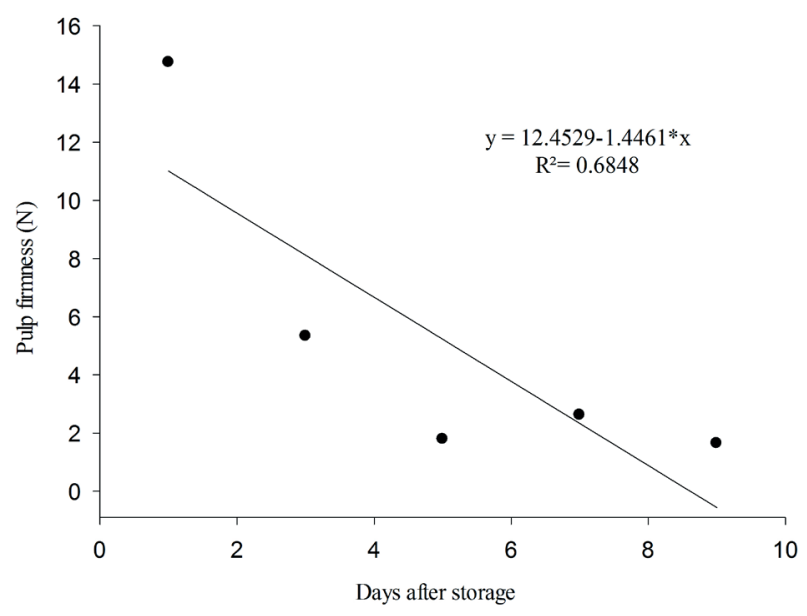

Figure 3. Pulp firmness variation of 'Prata-Anã' bananas, in ambient conditions, after cold storage.

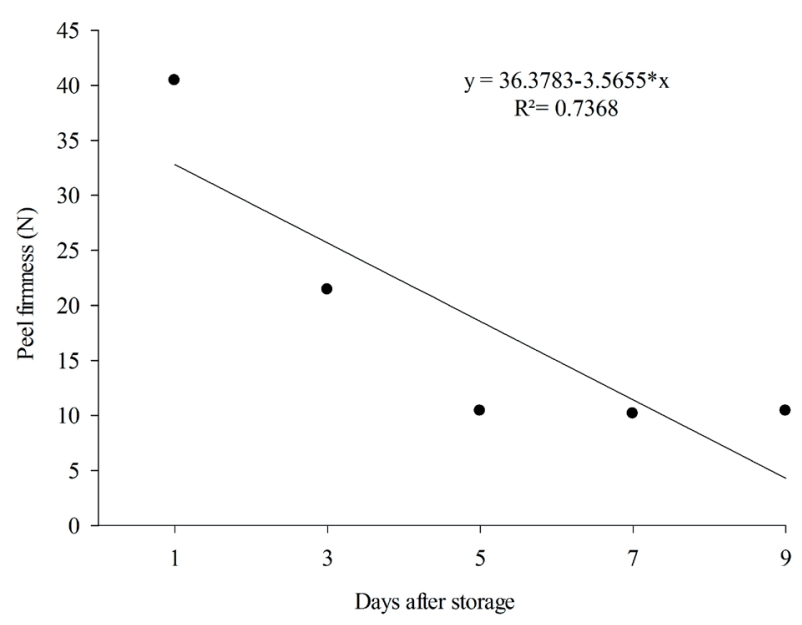

Figure 4. Peel firmness variation of 'Prata-Anã' bananas, in ambient conditions, after cold storage.
Regardless of the bunch age, there was a reduction in the $\mathrm{pH}$ values during the 9 days of evaluation after the fruits were withdrawn from the cold room (Figure 6). It was observed that the $\mathrm{pH}$ decreased as maturation progressed and, for days 1 , 3, 5, 7 and 9 after cold storage, the observed values were 5.38, 4.95, 4.9, 4.98 and 4.78, respectively. A decrease in the $\mathrm{pH}$ is expected with the ripening of the fruit, since a decrease may be associated with the accumulation of sugar and acidic constituents as the fruit ripens (Nascimento Junior et al. 2008).

There was a significant interaction between bunch age and days of evaluation for titratable acidity. Bananas from bunches of all ages showed an increase in acidity and a subsequent decrease.

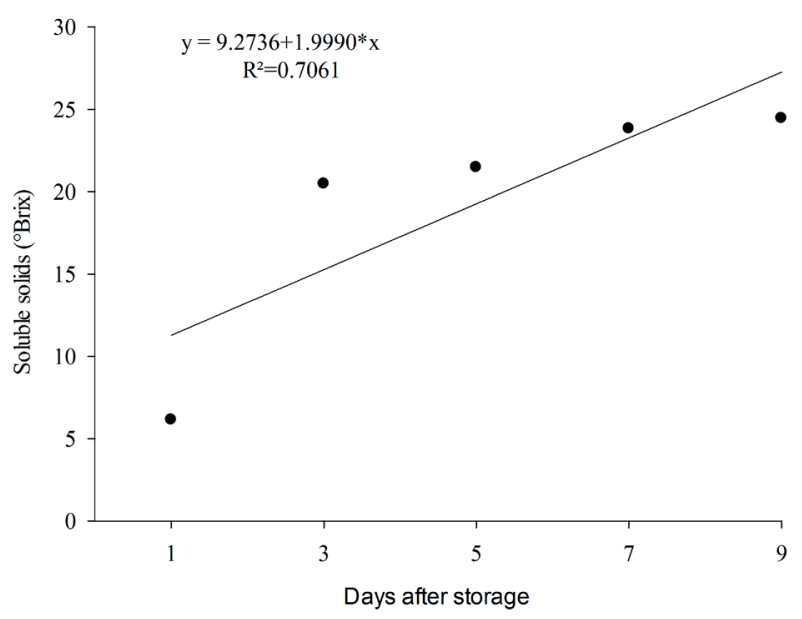

Figure 5. Variation of soluble solids contents of 'Prata-Anã' bananas, in ambient conditions, after cold storage.

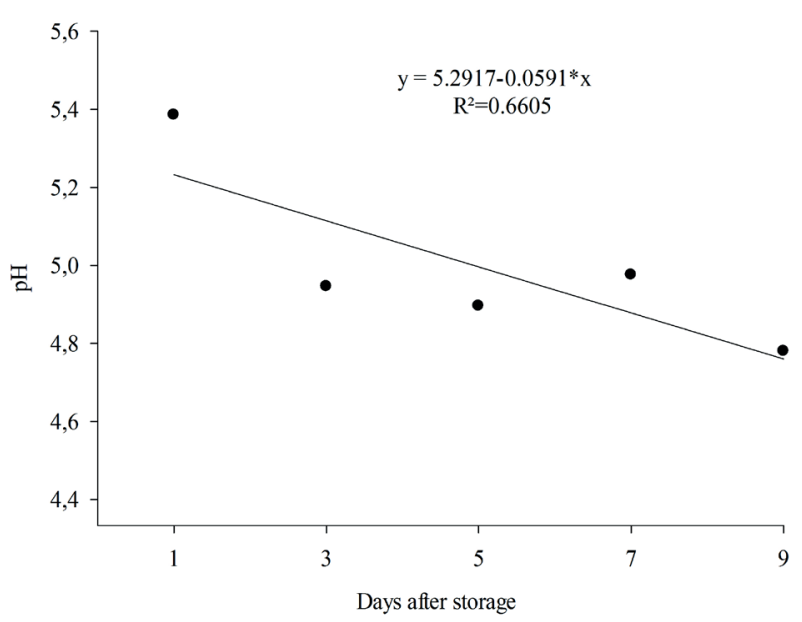

Figure 6. $\mathrm{pH}$ variation in 'Prata-Anã' bananas pulp, in ambient conditions, after cold storage. 
In the present experiment, the values found varied from $0.30 \mathrm{~g}$ to $0.50 \mathrm{~g}$ of malic acid $* 100 \mathrm{~g}^{-1}$, up to the fourth day of evaluation, reducing to $0.42 \mathrm{~g}$ of malic acid $* 100 \mathrm{~g}^{-1}$ at the last day, in view of the use of acids in the fruit respiration process (Figure 7). This increase in titratable acidity may be explained by the solubilization of pectic substances during the enzymatic activity occurring in the ripening process (Prill et al. 2012). Results obtained by Pimentel et al. (2010) confirm this behavior in studies with 'PrataAnã' bananas, which showed values for titratable acidity of $0.18 \%$ for green fruits, and titratable acidity of $0.69 \%$ for ripe fruits. Falcão et al. (2017), analyzing 'Prata-Anã' bananas, found values of $0.44 \mathrm{~g}$ of malic acid $* 100 \mathrm{~g}^{-1}$ after withdrawal from the cold room $\left(13{ }^{\circ} \mathrm{C} \pm 1.0^{\circ} \mathrm{C}\right.$ and relative humidity of $60-75 \%$ ).

The fruit starch contents after withdrawal from the cold room ranged from $11.08 \%$ to $12.69 \%$, for the different ages studied. Probably, the hydrolysis of starch had already initiated during the cold storage, thus showing lower values than those mentioned in the literature (18-20.99\%), even though they were green in color (Martins et al. 2007, Peroni-Okita et al. 2010). The values for starch at 9 days after withdrawal from the cold room were $4.07 \%, 2.74 \%$, $2.62 \%, 3.01 \%$ and $2.84 \%$, respectively at the ages of

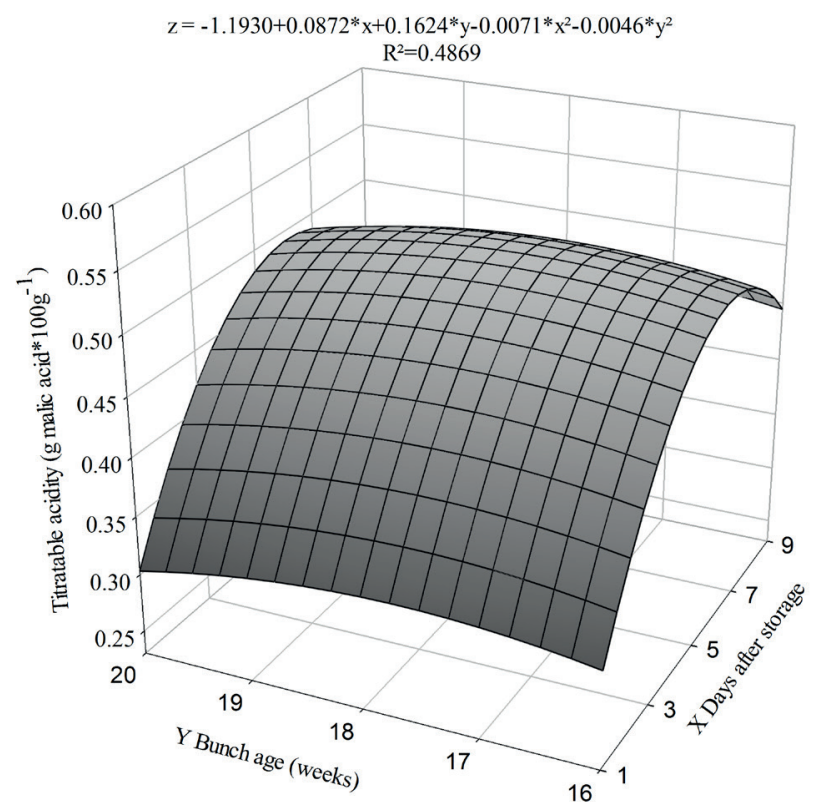

Figure 7. Titratable acidity variation of 'Prata-Anã' bananas separated from bunches at different ages, in ambient conditions, after cold storage.
$16,17,18,19$ and 20 weeks (Figure 8). This variation may be due to the different maturation times at which the fruits were separated from bunches. The 20 -week old fruits presented, on average, starch contents lower than those at 16, 17, 18 and 19 weeks, suggesting a more advanced maturity stage. This possibility is reinforced in studies by Silva et al. (2006), PeroniOkita et al. (2010) and Martins et al. (2007), who, when studying the starch content variation of 'PrataAnã' and 'Cavendish' (Nanicão) banana varieties, found that the green fruits had higher starch contents than ripe ones, indicating that the starch degradation occurs with ripening.

There was no significant interaction between bunch age days of evaluation for total sugars. Regardless of the bunch age, the fruits showed an increase from $4.05 \%$ to $25 \%$ of total sugars, over the days of evaluation (Figure 9). Santos et al. (2006) found average values of $22 \%$ of total sugars for 'Prata-Anã' bananas in the control treatment and a variation from $20.5 \%$ to $22.5 \%$ for fruits stored under controlled atmosphere conditions, both at $12.5^{\circ} \mathrm{C}$ and relative humidity of $98 \%$, for 40 days. Saraiva et al. (2013) also found, for 'Cavendish' (Nanica) bananas, during ripening, a $96 \%$ increase in the total soluble sugar contents and a $75 \%$ decrease in the starch contents.

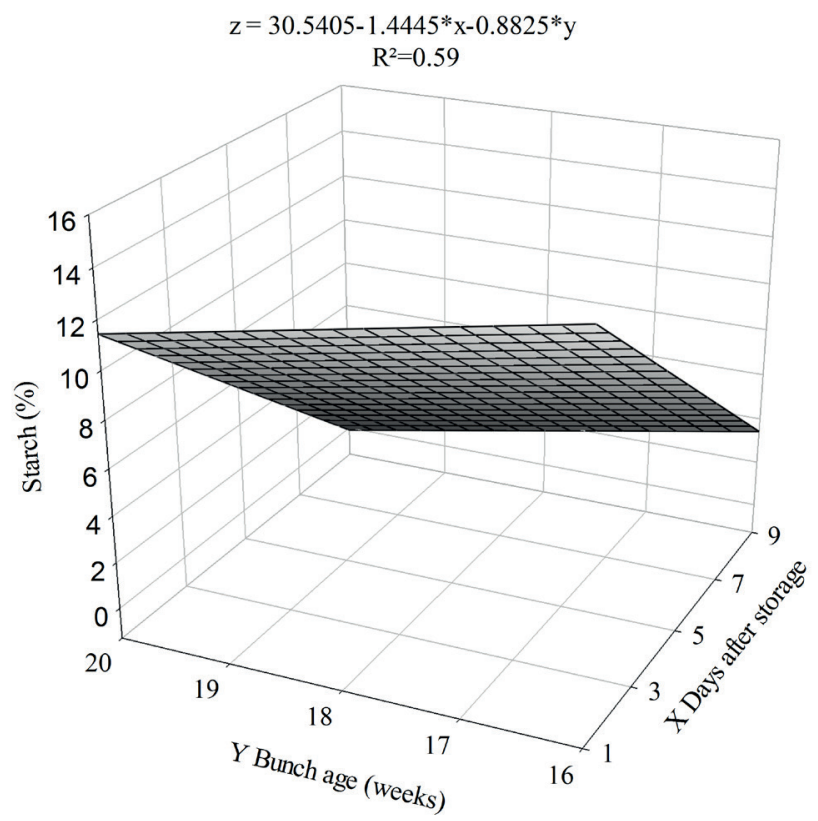

Figure 8. Starch content variation of 'Prata-Anã' bananas separated from bunches at different ages, in ambient conditions, after cold storage. 
After 25 days of cold storage, the reducing sugar contents were significant only in relation to the evaluation periods. Reducing sugar contents increased from $1.68 \%$ to close to $16.33 \%$ (Figure 10 ). Nogueira et al. (2007) also found that the reducing sugar contents increased during ripening, possibly due to the hydrolysis of starch and the inversion of sucrose into glucose and fructose.

Regardless of the bunch age, the non-reducing sugar contents were significant only in relation to the evaluation period, with a variation of $2.22 \%$ to $8.6 \%$, during the 9 days of evaluation (Figure 11). According to Coelho et al. (2007), the accumulation of soluble sugars, mainly glucose, fructose and sucrose, occurs due to the starch hydrolysis. Such

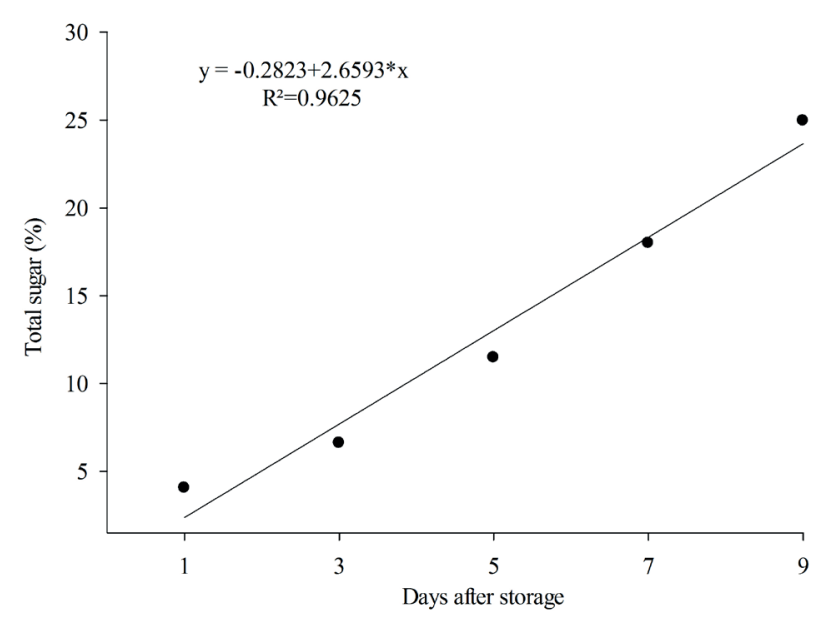

Figure 9. Variation of total sugar contents of 'Prata-Anã' bananas, in ambient conditions, after cold storage.

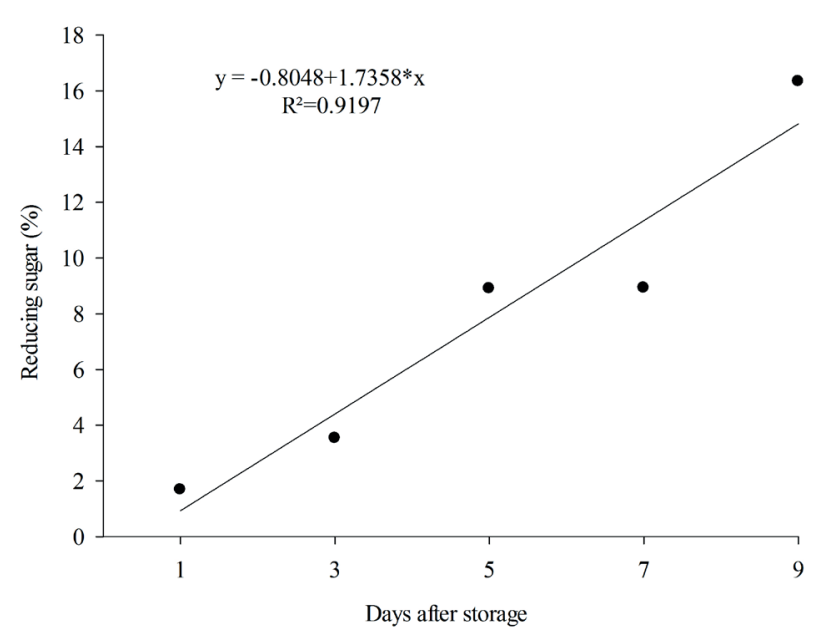

Figure 10. Variation of reducing sugar contents of 'Prata-Anã' bananas, in ambient conditions, after cold storage. sugars are oxidized and serve as basic substrates in the fruit respiration process.

As for electrolyte extravasation, an interaction between bunch age and days of evaluation was observed, being the fruits harvested at the age of 19 and 20 weeks the ones that showed higher levels of extravasation on the second day of evaluation, with $61.35 \%$ and $66.57 \%$, respectively (Figure 12 ). This probably happened because the fruits were already in the process of ripening and senescence. Fruits at

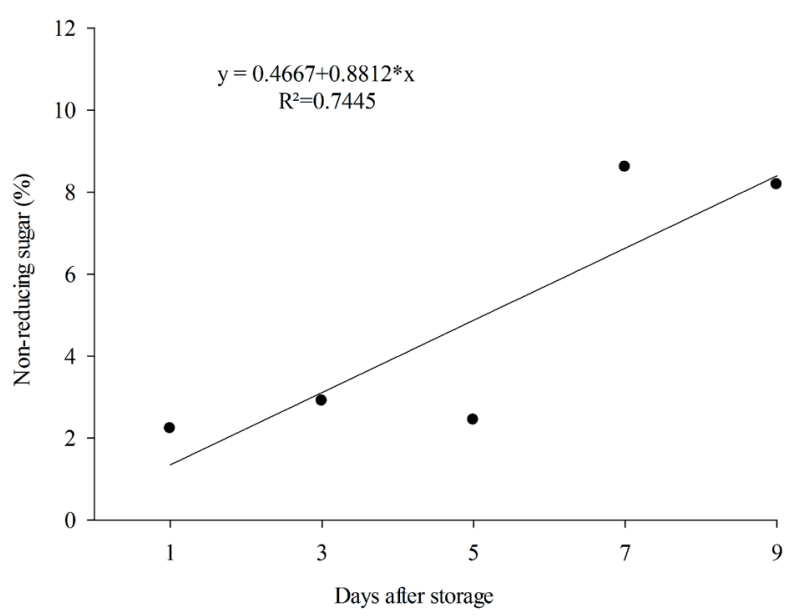

Figure 11. Variation of non-reducing sugars contents of 'PrataAnã' bananas, in ambient conditions, after cold storage.

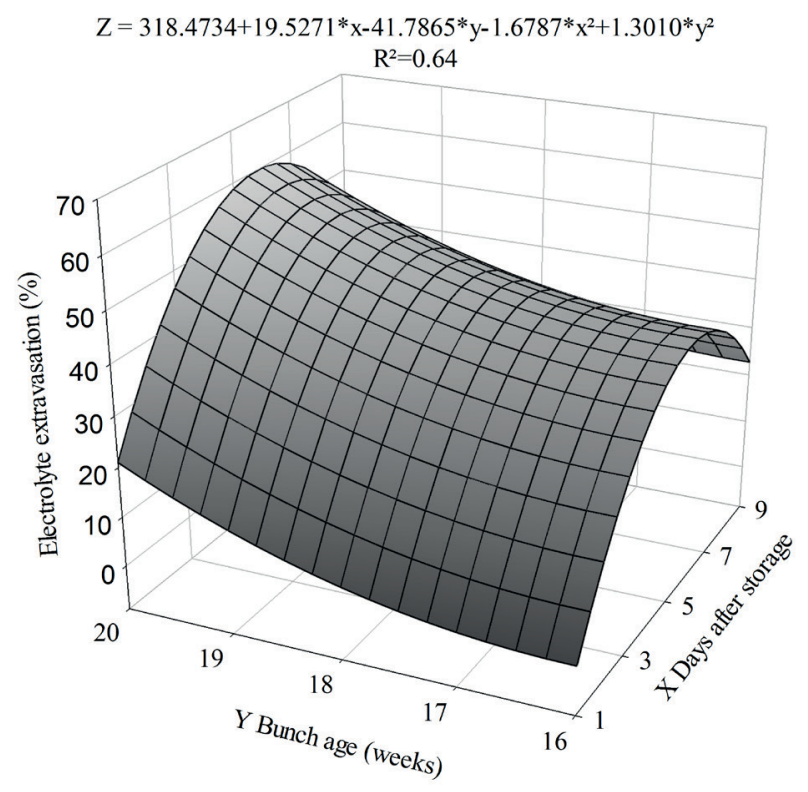

Figure 12. Variation of electrolyte extravasation of 'Prata-Anã' bananas separated from bunches at different ages, in ambient condition, after cold storage. 
the age of 16, 17 and 18 weeks showed a high and constant electrolyte loss during the evaluations, with the highest peak around the fourth day of evaluation, indicating a later maturation and, consequently, a better condition for post-harvest conservation.

\section{CONCLUSIONS}

1. Fruit age and storage temperature directly influence the physical and chemical characteristics of 'PrataAnã' bananas;

2. Bananas from bunches harvested at the ages of 19 and 20 weeks, when stored at $13.5^{\circ} \mathrm{C}$ for 25 days, are not recommended for being at an advanced maturity stage, thus having a lower capacity of post-harvest conservation;

3. 'Prata-Anã' bananas at the ages of 16, 17 and 18 weeks may be marketed up to 9 days after being stored for 25 days, at $13.5^{\circ} \mathrm{C} \pm 95 \%$ of relative humidity, without loss of quality.

\section{ACKNOWLEDGMENTS}

The authors thank the Fundação de Amparo à Pesquisa do Estado de Minas Gerais (Fapemig), for the financial support, as well as the Scientific Initiation Program of the Universidade Estadual de Montes Claros (Unimontes) - PIBIC/Fapemig.

\section{REFERENCES}

BORGES, A. L.; SOUZA, L. da S. Exigências edafoclimáticas. In: BORGES, A. L.; SOUZA, L. da S. (Eds.). O cultivo da bananeira. Cruz das Almas: Embrapa Mandioca e Fruticultura, 2004. p. 132-145.

CASTRICINI, A. et al. Caracterização pós-colheita e sensorial de genótipos de bananeiras tipo Prata. Revista Brasileira de Fruticultura, v. 37, n. 1, p. 27-37, 2015.

CHITARRA, M. I. F.; CHITARRA, A. B. Pós-colheita de frutos e hortaliças: fisiologia e manuseio. 2. ed. Lavras: UFLa, 2005.

COELho, D. A. et al. Avaliação da qualidade microbiológica de águas minerais comercializadas em supermercados da cidade de Alfenas, MG. Revista Higiene Alimentar, v. 21, n. 151, p. 88-92, 2007.

DISCHE, Z. General color reactions. In: WHISTLER, R. L.; WOLFRAM, M. L. Carbohydrate chemistry. New York: Academic Press, 1962. p. 477-512.
FALCÃO, H. A. S. et al. Armazenamento de variedades de bananas em condições de atmosfera modificada com permanganato de potássio. Revista de Agricultura Neotropical, v. 4, n. 4, p. 1-7, 2017.

FERREIRA, D. F. Sisvar: a computer statistical analysis system. Ciência \& Agrotecnologia, v. 35, n. 6, p. 10391042, 2011.

FOOD AND AGRICULTURAL ORGANIZATION OF THE UNITED NATIONS (FAO). Faostat. 2016. Available at: $<$ http://apps.fao.org/page/collections $>$. Access on: 27 Apr. 2018.

LICHTEMBERG, L. A. et al. Colheita, manuseio póscolheita e conservação dos frutos. In: FERREIRA, C. F. et al. (Eds.). O agronegócio da banana. Brasília, DF: Embrapa, 2016.

MARTINS, R. N. et al. Armazenamento refrigerado de banana 'Prata Anã' proveniente de cachos com 16, 18 e 20 semanas. Ciência e Agrotecnologia, v. 31, n. 5, p. 14231429, 2007.

MENDONÇA, K. et al. Concentração de etileno e tempo de exposição para desverdecimento de limão "Siciliano". Brazilian Journal of Food Technology, v. 6, n. 2, p. 179183, 2003.

MOHAPATRA, D. et al. Post-harvest processing of banana: opportunities and challenges. Food and Bioprocess Technology, v. 4, n. 3, p. 327-339, 2011.

NASCIMENTO JUNIOR, B. B. et al. Diferenças entre bananas de cultivares Prata e Nanicão ao longo do amadurecimento: características físico-químicas e compostos voláteis. Revista Ciência e Tecnologia de Alimentos, v. 28, n. 3, p. 649-658, 2008.

NELSON, N. A. A photometric adaptation of somogy method for the determination of glucose. The Journal of Biological Chemistry, v. 153, n. 2, p. 375-380, 1944.

NOGUEIRA, D. H. et al. Mudanças fisiológicas e químicas em bananas 'Nanica' e 'Pacovan' tratadas com carbureto de cálcio. Revista Brasileira Fruticultura, v. 29, n. 3, p. 460-464, 2007.

PERONI-OKITA, F. H. G. et al. In vivo degradation of banana starch: structural characterization of the degradation process. Carbohydrate Polymers, v. 81, n. 2, p. 291-299, 2010 .

PIMENTEL, R. M. A. et al. Qualidade pós-colheita dos genótipos de banana PA42-44 e Prata-Anã cultivados no norte de Minas Gerais. Revista Brasileira de Fruticultura, v. 32, n. 2, p. 407-413, 2010.

PRILL, M. A. S. et al. Atmosfera modificada e controle de etileno para bananas 'Prata-Anã' cultivadas na Amazônia setentrional brasileira. Revista Brasileira de Fruticultura, v. 34, n. 4, p. 990-1003, 2012. 
PROGRAMABRASILEIRO PARAAMODERNIZAÇÃO DAHORTICULTURA \& PRODUÇÃO INTEGRADADE FRUTAS (PBMH \& PIF). Normas de classificação de banana. São Paulo: Ceagesp, 2006. (Documentos, 29).

SANTOS, C. M. S. et al. Influência da atmosfera controlada sobre a vida pós-colheita e qualidade de banana 'Prata Anã'. Ciência e Agrotecnologia, v. 30, n. 2, p. 317322, 2006.

SARAIVA, L. A. et al. Black leaf streak disease affects starch metabolism in banana fruit. Journal of Agricultural and Food Chemistry, v. 61, n. 23, p. 5582-5589, 2013.

SARMENTO, D. H. A. et al. Armazenamento de banana 'Prata Catarina' sob temperatura ambiente recobertas com fécula de mandioca e PVC. Revista Caatinga, v. 28, n. 2, p. 235-241, 2015.
SARMENTO, J. D. A. et al. Qualidade pós-colheita de banana submetida ao cultivo orgânico e convencional. Revista Brasileira de Produtos Agroindustriais, v. 14, n. 1, p. 85-93, 2012.

SERPA, M. F. P. et al. Conservação de manga com uso de fécula de mandioca preparada com extrato de cravo e canela. Revista Ceres, v. 61, n. 6, p. 975-982, 2014.

SILVA, C. S. et al. Amadurecimento da banana-prata climatizada em diferentes dias após a colheita. Ciência e Agrotecnologia, v. 30, n. 1, p. 103-111, 2006.

WHILTON, T. H. et al. An improved method for using electrolyte leakage to access membrane competence in plant tissues. Plant Physiology, v. 98, n. 1, p. 198-205, 1992. 